\title{
Combined Effect of Chemical Treatment and Modified Atmosphere Packaging on Physicochemical Properties of Fresh-Cut Pear
}

\author{
Ram Prakash Kumar ${ }^{1 *}$ and Tankesh Kumar ${ }^{2}$ \\ ${ }^{1}$ Department of Agricultural and Food Engineering, Indian Institute of Technology, \\ Kharagpur, India \\ ${ }^{2}$ Department of Processing and Food Engineering, Acharya N. G. Ranga Agricultural \\ University, Guntur, Andhra Pradesh, India \\ *Corresponding author
}

\section{Key w o r d s \\ Modified atmosphere packaging, Chemical treatment, Firmness, Color, Scanning electron microscope-energy dispersive X-ray (SEM- EDX) analysis \\ Article Info \\ Accepted: \\ 07 October 2018 \\ Available Online: \\ 10 November 2018}

\section{A B S T R A C T}

The effect of modified atmosphere packaging (MAP) with chemical treatment on physicochemical quality fresh-cut pears was investigated. Cut-pears were subjected to the following conditions: (1) MAP + Treated - $\left(1 \%\right.$ citric acid $\left.+1 \% \mathrm{CaCl}_{2}\right)$ and stored in MAP at $8{ }^{\circ} \mathrm{C},(2)$ Treated - $\left(1 \%\right.$ citric acid $\left.+1 \% \mathrm{CaCl}_{2}\right)$ and stored at room temperature and regular atmosphere, (3) MAP + Untreated - No chemical treatment and stored in MAP at 8 ${ }^{\circ} \mathrm{C}$, (4) Untreated - No chemical treatment and stored at room temperature and regular atmosphere. Changes in physiological loss of weight (PLW), firmness, $\mathrm{pH}$, total soluble solids (TSS), titratable acidity, color, scanning electron microscope-energy dispersive Xray (SEM-EDX) and sensory characteristics were evaluated at $8^{\circ} \mathrm{C}$ for 8 days. Firmness and titratable acidity continuously decreased while PLW, $\mathrm{pH}$, and TSS continuously increased from their initial values for all conditions. ' $L$ ' values decreased, ' $a$ ' and ' $b$ ' values increased during storage. Firmness and color were better maintained in MAP + Treated pear among all other samples. SEM-EDX analysis revealed that the surface of chemically treated sample was smoother than untreated sample. In the sensory test the panellists could not find any significant difference between freshly cut-pear and MAP + treated cut-pears at the end of storage period. These results suggested that fresh-cut pears could be stored maintaining its original quality for long time by chemical treatment of $1 \%$ citric acid $+1 \% \mathrm{CaCl}_{2}$ in combination with MAP.

\section{Introduction}

Pear (Pyrus communis L.) is a highly valued fruit for its flavor and nutritional quality. It contains large amount of dietary fiber, vitamins, protein, minerals. According to the USDA National Nutrient Database for Standard Reference Legacy Release (2018), $100 \mathrm{~g}$ of pear contains $57 \mathrm{kcal}$ energy, $15.23 \mathrm{~g}$
Carbohydrate, 3.1 g Fiber,0.36 g Protein, 4.3 mg Vitamin C, $4.4 \mathrm{mg}$ Vitamin K, $116 \mathrm{mg}$ Potassium, $12 \mathrm{mg}$ Phosphorus, $9 \mathrm{mg}$ Calcium, $7 \mathrm{mg}$ Magnesium, and $1 \mathrm{mg}$ Sodium. It is packed with immense health benefits such as anti-inflammatory, sedative, anti-pyretic, antioxidants, hypolipidemic, hypoglycaemic, antiaging, anti-tussive, anti-diarrheal, and hepatoprotective (Parle and Arzoo, 2016). The shelf- 
life of freshly cut pear is very less and it undergoes frequent browning and texture loss in ambient condition. Browning in sliced fruits is caused by the oxidative reactions of phenolic substrates catalyzed by polyphenol oxidase (PPO) in the presence of atmospheric oxygen (Del Valle et al., 1998), and the fruit softening is due to enzyme-mediated alterations in the structure and composition of cell wall, partial or complete solubilization of cell wall polysaccharides triggered by ethylene (Tuckerand Grierson, 1987). Modified atmosphere packaging (MAP) is a technique used for prolonging the shelf-life of fresh or processed foods by modifying the air surrounding the food in the package to a different composition. Inside packages, $\mathrm{O}_{2}$ concentration is reduced while $\mathrm{CO}_{2}$ concentration is increased, causing a reduction in product's respiration rate and a consequent slowing down of senescence and decay phenomena (Das et al., 2006). However, modified atmosphere packaging (MAP) alone cannot completely control the post-cutting enzymatic browning and softening of fresh-cut fruits. There are numerous chemical preservation strategies used to reduce enzymatic browning and fruit softening such as citric acid, acetylcysteine-glutathione solution, and ascorbic acid as browning inhibitors (Park et al., 2010; Oms-Oliu et al., 2008; Soliva-Fortuny et al., 2007), and calcium chloride and lactateas firmnessmaintaining agent (Alandes et al., 2006). Combinations of modified atmosphere packaging (MAP) and chemical treatment have been successfully studied to increase the shelf-life of various fruits such as strawberry (Aguayo et al., 2006), banana (Vilas- Boas and Kader, 2006), apple (Rocculi et al., 2004) and fresh-cut pear (Sapers and Miller, 1998). Waghmare et al., (2013) found that chemical solution (1\% calcium chloride and $2 \%$ citric acid) and MAP was very effective in maintaining the quality of fresh-cut papaya for 25 days at ${ }^{\circ} \mathrm{C}$. Bico et al., (2009) reported that dipping into chemical solution $(0.5 \%$ ascorbic acid, $2 \%$ calcium chloride and $0.75 \%$ cysteine) combined with carrageenan coating plus storage under controlled atmosphere $(3 \%$ $\mathrm{O}_{2}$ and $10 \% \mathrm{CO}_{2}$ ) could be a good method to preserve fresh-cut bananas for 5 days at $5^{\circ} \mathrm{C}$.

The main aim of this study was to evaluate the combined effect of chemical treatment and MAP on the physicochemical properties and shelf life of freshly cut pear.

\section{Materials and Methods}

\section{Sample preparation}

The fresh William Bartlett variety pears were purchased from the local fruit market in Kharagpur. The pears were stored in refrigerator for 3 hours at $0^{\circ} \mathrm{C}$ to assure its freshness. The selected quantity of pears were washed by running tap water, dried by cotton and peeled by peeler manually. Each fruit was cut into 6-8 uniform wedges using sharp knife. The cut pears were dipped in water to avoid frequent surface browning by contact of air, then dried with tissue paper. The pear wedges were dipped in a premade chemical solution of $1 \%$ citric acid and $1 \%$ calcium chloride for 5 minutes. Calcium chloride and citric acid have FDA GRAS status for use as browning inhibitors and firming agent (Code of Federal Regulations 21: 184.1193 and 21: 184.1033, respectively). The samples were removed from the container and put in a glass plate. Excess water was drained off and approximately $100 \mathrm{~g}$ portions of pear cubes were packaged in polypropylene bags under modified atmospheric conditions. The size of polypropylene bags was $12 \times 20 \mathrm{~cm}$ from inside and $0.025 \mathrm{~mm}$ thickness having gas permeability of $2660 \mathrm{cc} \mu \mathrm{m} \mathrm{m}^{-2} \mathrm{~h}^{-1}$ for $\mathrm{O}_{2}$ and $14958 \mathrm{cc} \mu \mathrm{m} \mathrm{m}^{-2} \mathrm{~h}^{-1}$ for $\mathrm{CO}_{2}$ at 1 atm. The bags were sealed using a Continuous Band Sealer (MS Horizontal 770 Type FR 900-A, Apple Automation and Sensor, Maharashtra, 
India). Pear slices were subjected to four different treatments: (1) Map + Treated - (1\% citric acid $+1 \% \mathrm{CaCl}_{2}$ ) and stored in MAP at $8{ }^{\circ} \mathrm{C}$, (2) Treated - (1\% citric acid $\left.+1 \% \mathrm{CaCl}_{2}\right)$ and stored at room temperature and regular atmosphere, (3) MAP + Untreated - No chemical treatment and stored in MAP at $8{ }^{\circ} \mathrm{C}$, (4) Untreated - No chemical treatment and stored at room temperature and regular atmosphere. The samples of all groups were replicated three times and stored for 8 days.

\section{Measurement of physicochemical properties}

\section{Physiological loss in weight (PLW)}

Physiological loss in weight (PLW) of cut fruit was calculated as percentage loss in weight based on the initial weight (before storage) and final weight (recorded at the time of periodical analysis during storage) (Shankar et al., 2009).

$$
\begin{gathered}
\text { Initial weight }- \text { Final weight } \\
\text { Initial weight }
\end{gathered}
$$

\section{Firmness}

The texture characteristic of cut fruit in terms of firmness was measured using a texture analyzer (TA-XT2i, Stable Micro System Ltd., UK). The analyser was linked to a computer that recorded data. The studies were conducted at a pre-test speed of $1.0 \mathrm{~mm} / \mathrm{s}$, test speed of $0.5 \mathrm{~mm} / \mathrm{s}$, distance of $30 \mathrm{~mm}$, and load cell of $50.0 \mathrm{~kg}$ (Sirisomboon et al., 2000). Firmness value was considered as mean peak cutting force and expressed in $\mathrm{N}$.

\section{pH-value}

$\mathrm{pH}$-value of pear fruit was measured with a digital $\mathrm{pH} / \mathrm{mV} /{ }^{\circ} \mathrm{C}$ Analyzer $\left(\mu \mathrm{pHCal}{ }_{5}\right.$, Analab Scientific Instruments Pvt. Ltd., Gujarat, India) according to AOAC (2005) procedure.

\section{Total soluble solids (TSS)}

Total soluble solids (TSS) in the pear fruit was determined using a digital refractometer (PAL-3, Atago Company Ltd., Japan)

At $20^{\circ} \mathrm{C}$ and expressed as ${ }^{\circ}$ Brix following the method prescribed by AOAC (2005).

\section{Titratable acidity}

Titratable acidity of pear cut-fruit was determined by titrating against $0.1 \mathrm{~N}$ sodium hydroxide $(\mathrm{NaOH})$ using phenolphthalein as indicator (AOAC, 2005). Titratable acidity as $\mathrm{mg}$ of malic acid per $100 \mathrm{ml}$ of pear juice was calculated by using following formula:

Titre $\times$ Normality of $\mathrm{NaOH} \times$ Vol. made up $\times$ eq. wt. of acid $\times 100$

$\%$ Acidity $=$

Vol. of sample taken for estimation $\times$ Vol. of sample taken $\times 1000$

\section{Color}

The colour of fruit was measured using Chromameter Minolta CR-400 (Konica Minolta sensing Inc., Japan) and the results were expressed in accordance with the Hunter L, a, b color measuring system (AOAC, 2005). Hunter value ' $L$ ' varies from 0 to 100 where ' 100 ' indicates white and ' 0 ' indicates black, 'a' varies from 'greenness to ' + ' value indicating redness, and 'b' varies from '-' value indicating blueness to ' + ' value indicating yellowness.

\section{Scanning electron microscope-Energy dispersive X-ray (SEM-EDX) Analysis}

The SEM-EDX Analysis for microstructural and elemental studies of the samples was done using a scanning electron microscope with energy dispersive X-ray (Sigma 300 VP, Carl Zeiss Ltd., UK). 


\section{Sensory evaluation}

Sensory analyses of treated and untreated pear wedges stored with and without MAP were carried out at end of storage period to evaluate consumer acceptability (Ranganna, 2001). Ten consumers, between 20 and 30 years old, were recruited among students and personnel of the Department of Agricultural and food engineering, IIT-Kharagpur.

The panelists evaluated the acceptability of the samples from the point of view of odor, color, taste, and firmness using a 9-point Hedonic scale where 1 indicated extreme dislike and 9 indicated extreme like. Results were compared with those obtained for freshly processed samples.

\section{Results and Discussion}

\section{Physiological loss of weight (PLW)}

The physiological loss of weight (PLW) increased sharply for both the untreated and treated pear (Fig. 1). The maximum PLW was found to be $31.5 \%$ in untreated pear and the minimum PLW was found to be $7.2 \%$ in MAP with treated pear at the end of $8^{\text {th }}$ days.

This could be mainly due to continuous loss of moisture due to transpiration from the fruit and respiration. Similar results were found by Bico et al., (2009) for banana.

\section{Firmness}

The maximum firmness observed was $29 \mathrm{~N}$ in MAP with treated sample and the minimum firmness observed was $11 \mathrm{~N}$ in untreated sample after $8^{\text {th }}$ days (Fig. 2). The firmness is directly related to loss of water i.e. weight loss. The reason for decrease in firmness during storage of pear fruits might be due to break down of enzymes, loss of water and degradation of pectic substances present in the fruits. Galvis-Sanchez et al., (2003) and Drake et al., (2004) reported similar findings in pear fruits during storage.

\section{pH-value}

$\mathrm{pH}$-value was observed to be increased in all four types of sample stored in different conditions. $\mathrm{pH}$-value of the untreated pear without MAP showed the maximum variation, while MAP + treated pear showed the lowest variation during storage (Fig. 3). The $\mathrm{pH}-$ value of fruit represents maturity and ripening level of commodity.

\section{Total soluble solids (TSS)}

It was observed that total soluble solids (TSS) increased in all samples with storage period (Fig. 4). The minimum variation in TSS was observed in both the MAP + treated and MAP + untreated samples. The maximum TSS (23.6 ${ }^{\circ}$ Brix) was observed in untreated sample stored in ambient air at end of storage period. Increase in TSS during storage might be associated with the transformation of pectic substances and starch hydrolysis and also with dehydration of fruits (Carrillo et al., 2003).

Slow increment in TSS during storage in packed sample was due to production of higher levels of $\mathrm{CO}_{2}$, which may lead to less physiological processes of fruits for slow ripening.

\section{Titratable acidity}

The titratable acidity of the samples irrespective of treatment decreased linearly throughout the storage period (Fig. 5). Decrease in acidity indicates the increase in ripening level of commodity. There was little variation in total titratable acidity between treated and untreated sample stored in MAPtechnique. Similar, pattern was observed in sample stored in ambient condition. 
Fig.1 Variation in physiological loss of weight of cut-pear during storage period

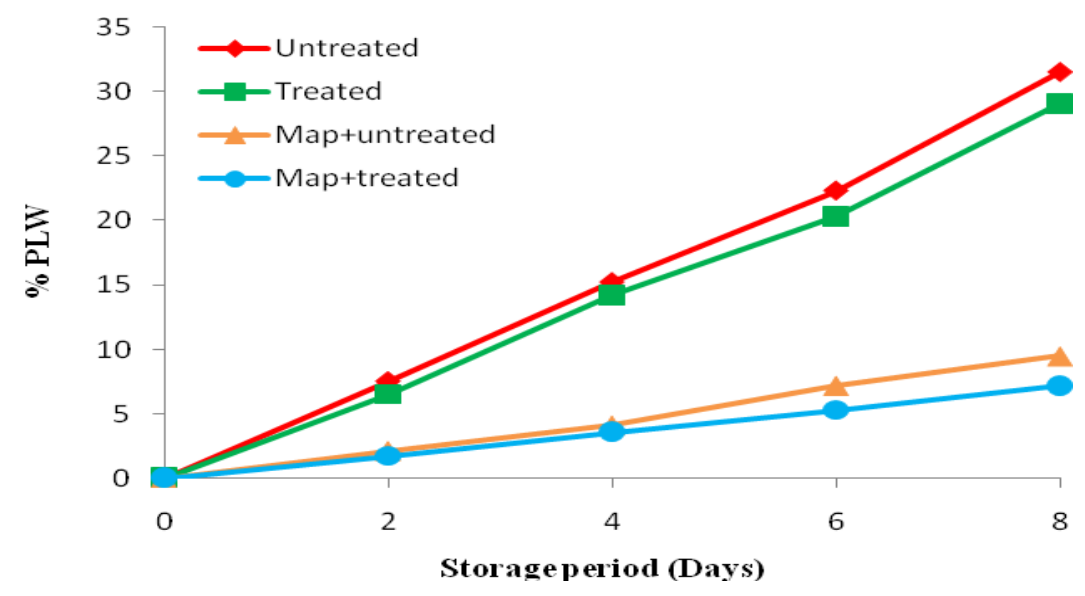

Fig.2 Variation in firmness of cut-pear during storage period

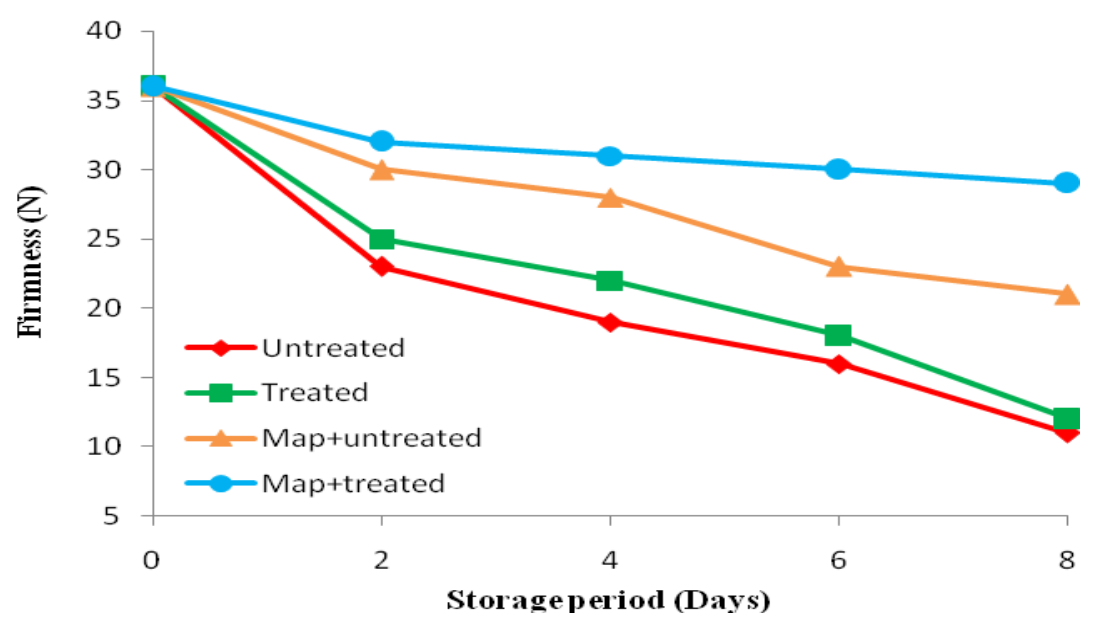

Fig.3 Variation in $\mathrm{pH}$-value of cut-pear during storage period

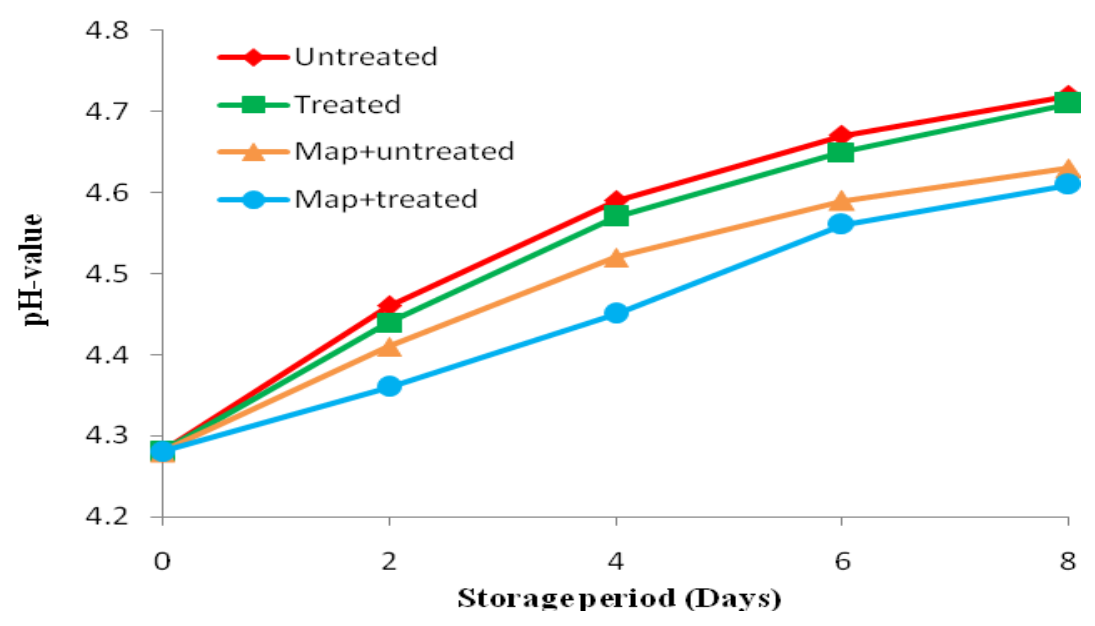


Fig.4 Variation in TSS juice during storage period

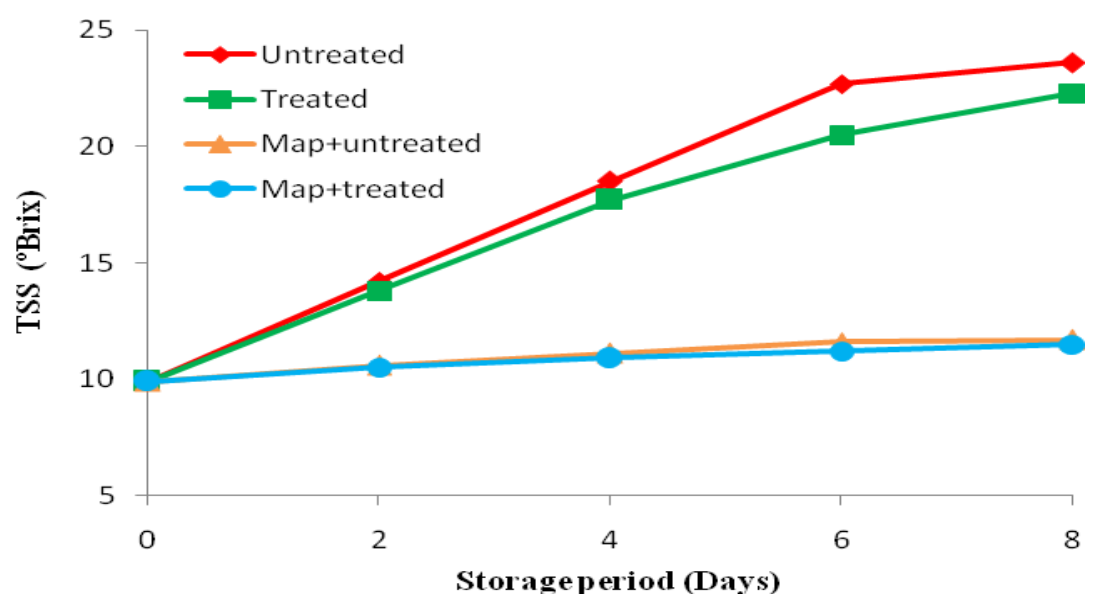

Fig.5 Variation in Titratable acidity juice during storage period

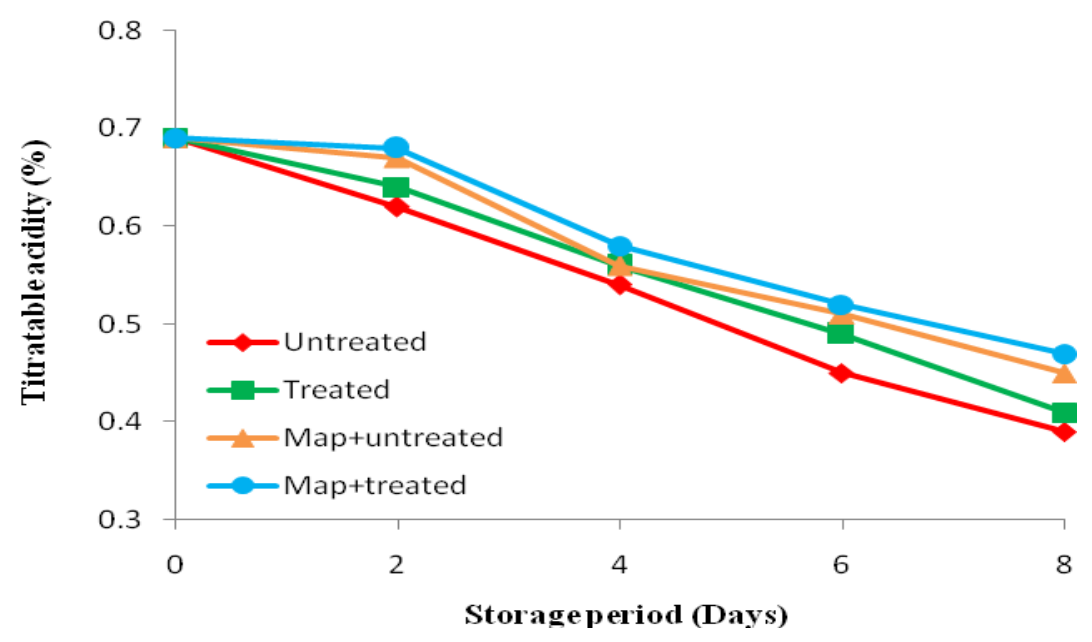

Fig.6 Variation in color of cut pear during storage period

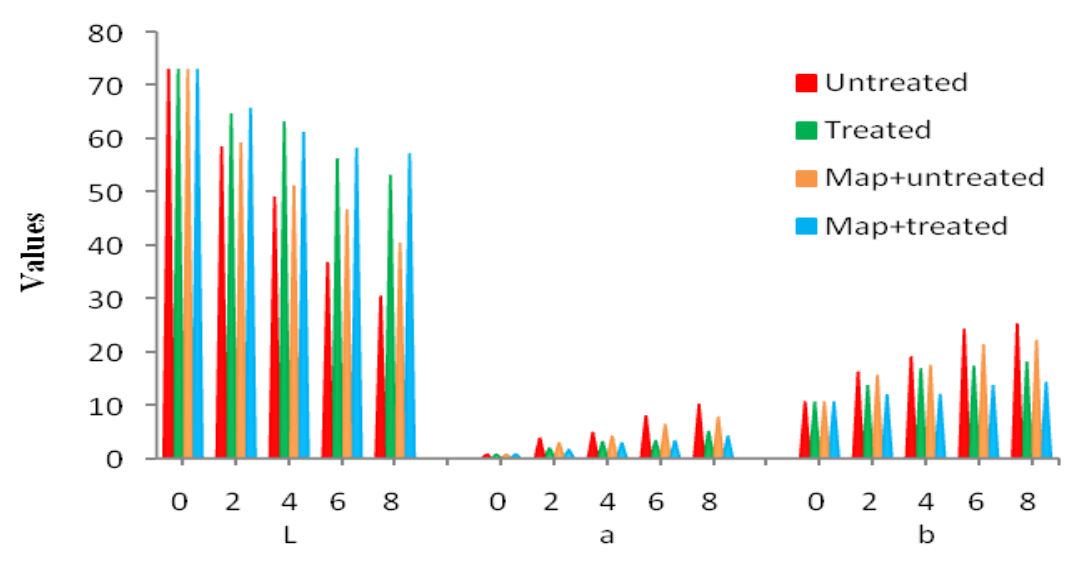

Color Parameters 
Fig.7 Results of SEM and EDX analysis

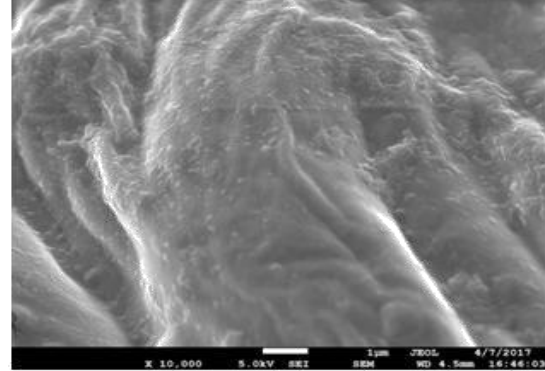

Chemically Treated Sample

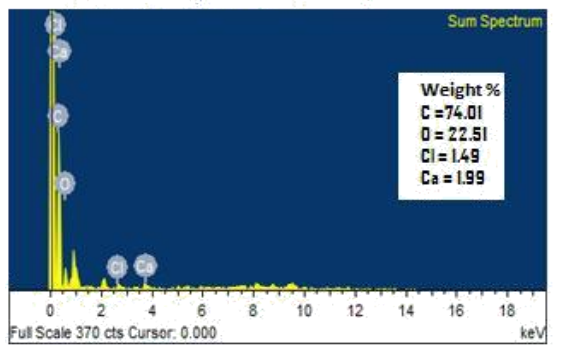

EDX results Chemically Treated Sample

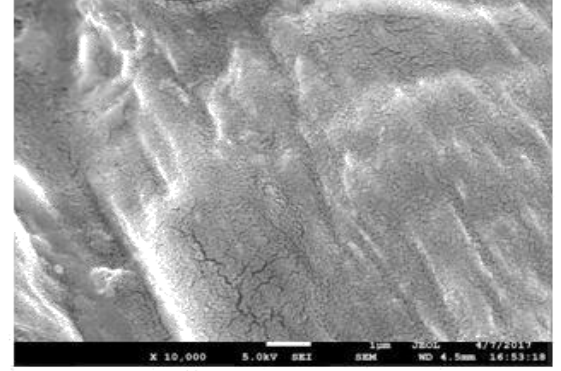

Untreated Sample

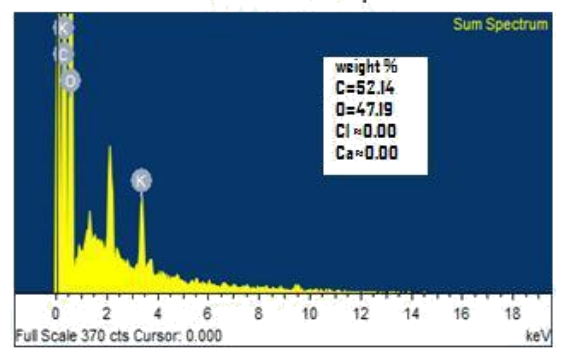

EDX results Untreated Samble

Fig.8 Sensory analysis of cut-pear at the end of storage period

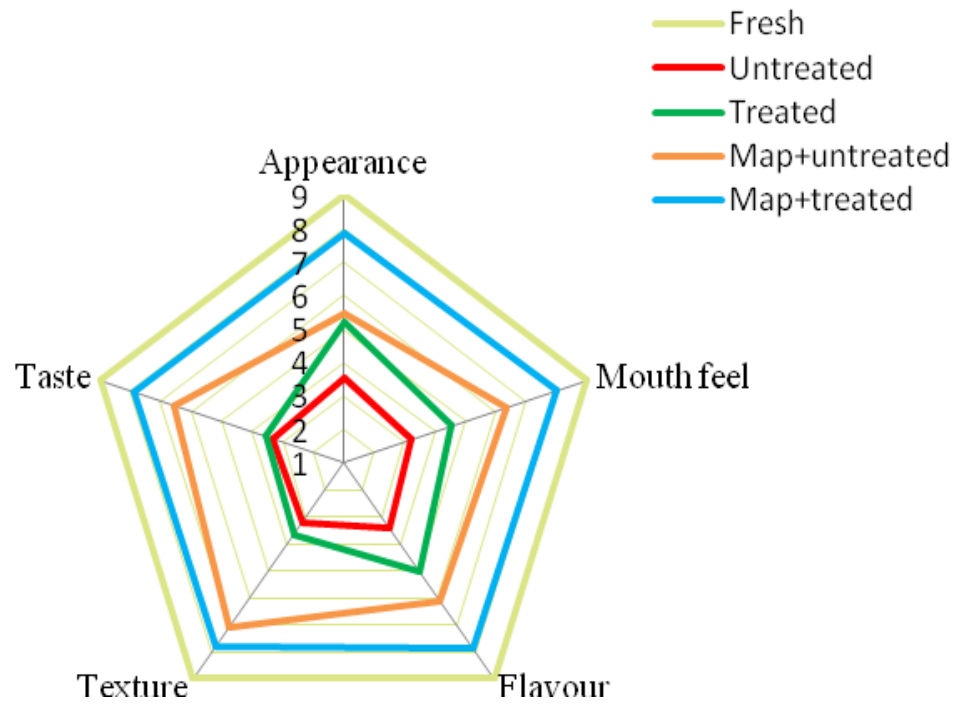

The minimum titratable acidity of $0.37 \%$ was recorded in untreated pear stored in ambient air. The reduction in acidity during storage might be associated with the conversion of organic acids into sugars and their derivatives or their utilization in respiration (Zerbini, 2002).

\section{Color}

The change in color of cut-pear samples during storage is shown in Figure 6. The maximum color change was observed in untreated pear without MAP which may be due to direct of contact of surplus amount of 
air, resulting enzymatic browning took place. The minimum color change was found in MAP plus chemically treated samples. The values of ' $L$ ' (brightness) were observed to be decreased for all treatments during storage time. The minimum values of ' $\mathrm{L}$ ' were found to be 30.51 and 40.5 for untreated pear without and with MAP, respectively; while the maximum values of ' $L$ ' were found to be 53.21 and 57.26 for treated pear without and with MAP, respectively. It shows that MAPtechnique alone is not effective for reducing the browning. The values of ' $a$ ' (redness) and ' $b$ ' (yellowness) in terms of brownness increased in all samples during storage time. The maximum value of 'a' was 10.23 for untreated sample (without MAP) and the minimum value was 4.27 for MAP with treated sample. The maximum value of ' $b$ ' was 24.32 for untreated without MAP while the minimum value was 4.27 for MAP with treated sample.

\section{SEM-EDX analysis}

The microstructural and elemental characteristics of both treated and untreated samples are shown in Figure 7. The surface of chemically treated sample was smoother than untreated sample. It was mainly due to treatment with calcium chloride (firming agent) which was also identified in EDX result. More oxygen $(47.19 \%)$ and less carbon $(52.14 \%)$ were observed in untreated sample than treated one $(\mathrm{O}=22.51 \%$ and $\mathrm{C}=74.01 \%)$ which may be due to oxidation in untreated sample during storage period.

\section{Sensory evaluations}

On $8^{\text {th }}$ day of storage period, chemically treated cut-pear along with MAP scored higher (>7.8) than the other samples for overall sensory attributes (Fig. 8). Sensory evaluation results revealed that there was no discernible between fresh and MAP +
Treated samples at the end of storage period. The lowest score $(<3.5)$ was obtained for untreated sample in overall acceptability which was not acceptable by the panel largely due to significant shrivelling and browning.

According to the results obtained in this study MAP alone did not effectively prevent cut surface browning or firmness loss in fresh-cut pear slices. A post-cutting dips of $1 \% \mathrm{CaCl}_{2}+$ $1 \%$ citric acid and MAP treatment, significantly extended shelf-life of the slices by inhibiting loss of firmness and cut surface browning. Overall, this treatment was found effective in maintaining physicochemical and sensory characteristics of fresh-cut pear during 8-day storage at $8{ }^{\circ} \mathrm{C}$ compared with other treatments. Sensory analysis of the MAP + chemical treated slices showed no objectionable unpleasant attributes for the panelistson $8^{\text {th }}$ day of storage. Use of this combination to inhibit enzymatic browning and deterioration of fresh-cut fruits may help fresh-cut processors to overcome the significant hurdles that currently impede the commercial development of fresh-cut fruit products.

\section{References}

Aguayo, E., Jansasithorn, R., and Kader, A. A. (2006). Combined effects of 1methylcyclopropene, calcium chloride dip, and/or atmospheric modification on quality changes in fresh-cut strawberries. Postharvest Biology and Technology, 40 269-278.

Alandes, L., Hernando, I., Quiles, A., PerezMunuera, I., and Lluch, M. A., 2006. Cell wall stability of fresh-cut Fuji apples treated with calcium lactate. Journal of Food Science 71(9), 615620.

AOAC. (2005). Official Methods of Analysis. $18^{\text {th }}$ ed. The Association of the Official Analytical Chemists. Maryland, USA. 
Bico, S. L. S., Raposo, M. F. J., Morais, R. M. S. C., and Morais, A. M. M. B. (2009). Combined effects of chemical dip and/or carrageenan coating and/or controlled atmosphere on quality of fresh-cut banana. Food Control, 20, 508-514.

Carrillo, L. A., Cruz-Hernandez A, GuevaraLara F., and Paredes-Lopez, O. (2003). Physico-chemical changes during ripening in storage of two varieties of prickly pear stored at $18{ }^{\circ} \mathrm{C}$. Journal of Food Science and Technology, 40, 461464.

Das, E., Gurakan, G. C., and Bayindirli, A. (2006). Effect of controlled atmosphere storage, modified atmosphere packaging and gaseous ozone treatment on the survival of Salmonella Enteritidis on cherry tomatoes. Food Microbiology, 23, 430-438.

Del Valle, J.M., Aranguiz, V., and Leon H. (1998). Effects of blanching and calcium infiltration on PPO activity, texture, microstructure and kinetics of osmotic dehydration of apple tissue. Food Research International, 31(8), 557-569.

Drake, S. R. (1994). Elevated Carbon Dioxide Storage of Anjou' Pears Using Purgecontrolled Atmosphere. Horticultural Science, 29(4), 299-301.

FDA.Code of Federal Regulations. Food and Drug Administration. https://www.accessdata.fda.gov/scripts/ cdrh/cfdocs/cfcfr/CFRSearch.cfm?CFR Part $=184$

Galvis- Sanchez, A. C., Fonseca, S. C., Morais, A. M. M. B., and Malcata, F. X. (2003). Physicochemical and sensory evaluation of 'Rocha' pear following controlled atmosphere storage. Journal of Food Science, 68(1), 318-327.

Oms-Oliu, G., Soliva-Fortuny, R., MartínBelloso, O., (2008). Edible coatings with antibrowning agents to maintain sensory quality and antioxidant properties of fresh-cut pears. Postharvest Biology and Technology. 50 (1), 87-94.

Park, Y. S., \&Heo, B. G. (2010). Effect of anti-browning agent treatment on the quality of pear cv' Wonhwang' processed fresh-cut stored in cold temperature. The Korean Journal of Community Living Science, 21(1), 7179.

Parle, M., and Arzoo. (2016). Why is pear so dear. International Journal of Research in Ayurveda and Pharmacy, 7(1), 108113.

Ranganna, S. (2001). Hand book of analysis and quality control of fruit and vegetable products. Tata McGraw Hill Publication Co. Ltd., New Delhi.

Rocculi, P., Romani, S., \& Rosa, M. D. (2004). Evaluation of physico-chemical parameters of minimally processed apples packed in non-conventional modified atmosphere. Food Research International, 37(4), 329-335.

Sapers, G. M., and Miller, R. L. (1998). Browning inhibition in fresh-cut pears. Journal of Food Science, 63(2), 342346.

Shankar, V., Veeragavathatham, D., and Kannan, M. (2009). Effect of organic farming practices on post-harvest storage life and organoleptic quality of yellow onion (Allium cepa L.). Indian Journal of Agricultural Sciences, 79(8), 608-614.

Sirisomboon, P., Tanaka, M., Fujita, S., Kojima, T. (2000). Relationship between the texture and pectin constituents of Japanese pear. Journal of Texture Studies, 31(6), 679-690.

Soliva- Fortuny, R., Ricart- Coll, M., Elez- Martínez, P., and Martín- Belloso, O. (2007). Internal atmosphere, quality attributes and sensory evaluation of MAP packaged 
fresh- cut Conference pears. International Journal of Food Science and Technology, 42(2), 208-213.

Tucker, G. A., and Grierson, D. 1987. Fruit ripening. In: Davies, D. (Ed.). The Biochemistry of Plants. Vol. 12. pp. 265-319. Academic Press Inc., New York.

USDA National Nutrient Database for Standard Reference Legacy Release, 2018. https://ndb.nal.usda.gov/ndb/ foods $/$ show $/ 301224$ ? $\mathrm{manu}=\& \mathrm{fgcd}=\& \mathrm{ds}$ $=$ SR\&q $=$ Pears, $\% 20 \mathrm{raw}$

Vilas-Boas, E. V. de B., and Kader, A. A. (2006). Effect of atmospheric modification, 1-MCP and chemicals on quality of fresh-cut banana. Postharvest
Biology and Technology, 39(2), 155162.

Waghmare, R. B., and Annapure, U. S. (2013). Combined effect of chemical treatment and/or modified atmosphere packaging (MAP) on quality of freshcut papaya. Postharvest Biology and Technology, 85, 147-153.

Zerbini, P. E., Grassi, M., Cubeddu, R., Pifferi, A., and Torricelli, A. (2002). Non-destructive detection of brown heart in pears by time-resolved reflectance spectroscopy. Postharvest Biology and Technology, 25(1), 87-97.

\section{How to cite this article:}

Ram Prakash Kumar and Tankesh Kumar. 2018. Combined Effect of Chemical Treatment and Modified Atmosphere Packaging on Physicochemical Properties of Fresh-Cut Pear. Int.J.Curr.Microbiol.App.Sci. 7(11): 567-576. doi: https://doi.org/10.20546/ijcmas.2018.711.068 